$12-2018$

\title{
The Evacuation of Phnom Penh during the Cambodian Genocide: Applying Spatial Video Geonarratives to the Study of Genocide
}

\author{
James A. Tyner \\ Kent State University \\ Andrew Curtis \\ Kent State University \\ Sokvisal Kimsroy \\ Kent State University \\ Chhunly Chhay \\ Kent State University
}

Follow this and additional works at: https://digitalcommons.usf.edu/gsp

\section{Recommended Citation}

Tyner, James A.; Curtis, Andrew; Kimsroy, Sokvisal; and Chhay, Chhunly (2018) "The Evacuation of Phnom Penh during the Cambodian Genocide: Applying Spatial Video Geonarratives to the Study of Genocide," Genocide Studies and Prevention: An International Journal: Vol. 12: Iss. 3: 163-176.

DOI:

https://doi.org/10.5038/1911-9933.12.3.1607

Available at: https://digitalcommons.usf.edu/gsp/vol12/iss3/15

This is brought to you for free and open access by the Open Access Journals at Digital Commons @ University of South Florida. It has been accepted for inclusion in Genocide Studies and Prevention: An International Journal by an authorized editor of Digital Commons @ University of South Florida. For more information, please contact digitalcommons@usf.edu. 
The Evacuation of Phnom Penh during the Cambodian Genocide: Applying Spatial Video Geonarratives to the Study of Genocide

\section{Acknowledgements}

This research was funded in part by the College of Arts \& Sciences at Kent State University. We are grateful for the support of Dean Jim Blank. 


\title{
The Evacuation of Phnom Penh during the Cambodian Genocide: Applying Spatial Video Geonarratives to the Study of Genocide
}

\author{
James A. Tyner \\ Kent State University \\ Kent, Ohio, USA \\ Andrew Curtis \\ Kent State University \\ Kent, Ohio, USA \\ Sokvisal Kimsroy \\ Kent State University \\ Kent, Ohio, USA \\ Chhunly Chhay \\ Kent State University \\ Kent, Ohio, USA
}

\section{Introduction}

Between April 1975 and January 1979 the Communist Party of Kampuchea (CPK; better known as the "Khmer Rouge") carried out a program of state-led mass violence that resulted in the death of approximately two million men, women, and children. ${ }^{1}$ In just under four years approximately one-quarter of the country's pre-1975 population died. For many scholars and commentators, most emblematic of the Cambodian genocide is the forcible evacuation of Phnom Penh, Cambodia's capital and focal point of the country's political economy. Following the defeat of republican forces loyal to then-President Lon Nol, the Khmer Rouge began the evacuation of the city's population. Within days, upwards of 80 percent of Phnom Penh's inhabitants were forced to leave the city, most often on foot, to be relocated on rural cooperatives and work camps. The evacuation was arduous; and many people died along the way.

The standard interpretation of the evacuation, discussed ad nauseam, holds that the evacuation of Phnom Penh (and other cities and towns) is a case of urbicide, that is, the deliberate targeting and destruction of urban spaces. ${ }^{2}$ Martin Shaw, for example, contends that urbicide finds "its most extreme expression in the Khmer Rouge's emptying of Phnom Penh," while Ryan Bishop and Gregory Clancey describe the forcible evacuation as "the most infamous deurbanization of modern times." ${ }^{3}$ Scholars, by extension, premise the evacuation to be reflective of a supposed antiintellectual, anti-technological, and anti-urban penchant of the CPK.

Recent scholarship reassesses the standard explanations and calls to question previous interpretations of CPK policy and practice. ${ }^{4}$ In contrast to the standard account, for example, new documentary-based research argues that "the Cambodian city is no longer seen as an abandoned husk forcibly depopulated to support a utopian ideology" but instead cities throughout Democratic

${ }^{1}$ David Chandler, The Tragedy of Cambodian History: Politics, War, and Revolution since 1945 (New Haven: Yale University Press, 1999); Elizabeth Becker, When the War was Over: Cambodia and the Khmer Rouge Revolution (New York: Public Affairs, 1998); James A. Tyner, From Rice Fields to Killing Fields: Nature, Life, and Labor under the Khmer Rouge (Syracuse: Syracuse University Press, 2017).

${ }^{2}$ Kevin McIntyre, "Geography as Destiny: Cities, Villages and Khmer Rouge Orientalism," Comparative Studies in Society and History 38 (1996), 730-758.

${ }^{3}$ Ryan Bishop and Gregory Clancey, "The City-As-Target, or Perpetuation and Death," in Cities, War, and Terrorism: Towards an Urban Geopolitics, ed. Stephen Graham (Malden: Blackwell, 2004), 63; Martin Shaw, What is Genocide? (Malden: Polity Press, 2007), 75.

${ }^{4}$ Andrew Mertha, Brothers in Arms: Chinese Aid to the Khmer Rouge, 1975-1979 (Ithaca: Cornell University Press, 2014); James A. Tyner, "Violence, Surplus Production, and the Transformation of Nature during the Cambodian Genocide," Rethinking Marxism 26 (2014), 490-506; James A. Tyner, Samuel Henkin, Savina Sirik, and Sokvisal Kimsroy, "Phnom Penh during the Cambodian Genocide," Environment and Planning A: Economy and Space 46 (2014), 1873-1891; James A. Tyner and Stian Rice, “Cambodia's Political Economy of Violence: Space, Time, and Genocide under the Khmer Rouge, 1975-79," Genocide Studies International 10, no. 1 (2016), 84-94. 
Kampuchea - as the country was renamed-"re-emerged as pragmatic necessities to support the life-functions of rural production and consumption." ${ }^{5}$ In so doing, the CPK reorganized the urban geographies of Democratic Kampuchea in conformance with broader political-economic objectives, namely "to serve the people's livelihood, and to raise the people's standard of living quickly, both in terms of supplies and in terms of other material goods." ${ }^{\prime \prime}$ The CPK sought to achieve this objective through the satisfaction of a second objective, this being to "seek, gather, save, and increase capital from agriculture."7

Reinterpretations of the functions of cities within Democratic Kampuchea raises additional questions regarding the evacuation itself. If the purpose was not to destroy cities for ideological reasons but instead to transform urban areas to facilitate economic production, how are we to reinterpret the quotidian experience of evacuation? In this paper, we provide a preliminary, empirical reconstruction of the evacuation as experienced by survivors. Simply put, the broad skeleton of the evacuation is well understood; and myriad personal accounts provide flesh to bone. ${ }^{8}$ Missing, however, is a systematic reconstruction of lived experiences that takes seriously the fluid geographies of the Khmer Rouge evacuation. Stated differently, we seek to provide a geographically-informed account of the evacuation in order to provide a more fine-grained analysis of Khmer Rouge practice. In so doing, we draw on, and contribute to, the ongoing 'spatial turn' in genocide studies, notably, the application of geospatial technologies, including geographical information systems (GIS), to the study of historical and contemporary genocides. ${ }^{9}$ To this end, we utilize an innovative, spatially-grounded interview procedure, this being the spatial video geonarrative (SVG). ${ }^{10}$

Previous scholarship highlights the salience of personal narratives in genocide research. ${ }^{11}$ However, as Marguerite Madden and Amy Ross explain, the combination of geographic information science (GIScience) technologies with qualitative narrative data provides an opportunity to analyze critically spatial relationships of mass violence in ways not previously possible. ${ }^{12}$ Indeed, following Brittany Card and Isaac Baker, spatial data guides the analysis in identifying specific geographic areas of importance. ${ }^{13}$ The development of SVG, in particular, advances a spatial methodology

${ }^{5}$ Stian Rice and James A. Tyner, “The Rice Cities of the Khmer Rouge: An Urban Political Ecology of Rural Mass Violence," Transactions of the Institute of British Geographers, 42 (2017), 568.

${ }^{6}$ Party Center of the Communist Party of Kampuchea, "Preliminary Explanation Before Reading the Plan, by the Party Secretary," in Pol Pot Plans the Future: Confidential Leadership Documents from Democratic Kampuchea, 1976-1977, ed. David Chandler, et al. (New Haven: Yale University Press, 1988), 51.

${ }^{7}$ Ibid., 51.

${ }^{8}$ François Ponchaud, Cambodia Year Zero, translated by Nancy Amphoux (New York: Holt, Rinehart, and Winston, 1978); Loung Ung, First They Killed My Father: A Daughter of Cambodia Remembers (New York: Harper Collins, 2000); Vatey Seng, The Price We Paid: A Life Experience in the Khmer Rouge Regime, Cambodia (Lincoln: iUniverse, 2005).

${ }^{9}$ Marguerite Madden and Amy Ross, "Genocide and GIScience: Integrating personal Narratives and Geographic Information Science to Study Human Rights," The Professional Geographer 61, no. 4 (2009), 508-526; Waitman Beorn, Tim Cole, Simone Gigliotti, Alberto Giordano, Anna Holian, Paul B. Jaskot, Anne Kelly Knowles, Marc Masurovsky, and Erik B. Steiner, "Geographies of the Holocaust," Geographical Review 99, no. 4 (2009), 563-574; Anne K. Knowles, Tim Cole, and Alberto Giordano, eds. Geographies of the Holocaust (Indianapolis: Indiana University Press, 2014); Shelley J. Burleson and Alberto Giordana, "Extending Metadata Standards for Historical GIS Research: A Case Study of the Holocaust in Budapest and the Armenian Genocide in Turkey," International Journal of Applied Geospatial Research 6, no. 4 (2015), 88-109; Shelley J. Burleson and Alberto Giordana, "Spatiality of the Stages of Genocide: The Armenian Case," Genocide Studies and Prevention 10, no. 3 (2016), 39-58.

${ }^{10}$ Andrew Curtis, Jacqueline W. Curtis, Eric Shook, Steve Smith, Eric Jefferis, Lauren Porter, Laura Schuch, Chaz Felix, and Peter R. Kerndt, "Spatial Video Geonarratives and Health: Case Studies in Post-Disaster Recovery, Crime, Mosquito Control and Tuberculosis in the Homeless," International Journal of Health Geographics 14, no. 1 (2015), 22; Andrew Curtis, Jacqueline W. Curtis, Lauren C. Porter, Eric Jefferis, and Eric Shook, "Context and Spatial Nuance Inside a Neighborhood's Drug Hotspot: Implications for the Crime-Health Nexus," Annals of the American Association of Geographers 106, no. 4 (2016), 819-836.

${ }^{11}$ See for example Mary M. Clark, "Holocaust Video Testimony, Oral History, and Narrative Medicine: The Struggle Against Indifference," Literature and Medicine 24, no. 2 (2005), 266-282; Brittany L. Card and Isaac L. Baker, "GRID: A Methodology Integrating Witness Testimony and Satellite Imagery Analysis for Documenting Alleged Mass Atrocities," Genocide Studies and Prevention 8, no. 3 (2014), 49-61.

${ }^{12}$ Madden and Ross, Genocide and GIScience, 508.

${ }^{13}$ Card and Baker, GRID, 52. 
to capture and analyze 'lived experiences' and provides an excellent tool to collect and interpret data where none exists, or to add context to the spatial analysis of more conventional forms of oral histories and witness testimony. ${ }^{14}$ In particular, our advance is a relatively easily operated form of data collection and analysis whereby multiple geographically-grounded narratives can be overlaid to build a contextual interpretation of violent practice - in this case, that of the forcible evacuation of Phnom Penh.

\section{The Context of the Evacuation}

Between 1965 and 1973, military forces of the United States of America conducted aerial bombardment campaigns over, and a covert military incursion into, Cambodian territory to: (1) reduce the flow of arms and personnel from the Democratic Republic of Vietnam (DRV) to the Republic of Vietnam (RVN); (2) deprive the National Liberation Front (NLF; commonly known as the 'Viet Cong') of safe havens; and (3) support the broad objectives of communist 'containment' in Southeast Asia. ${ }^{15}$ The air campaign was especially devastating, as US forces dropped nearly 3 million tons of ordnance on Cambodia during this period, with casualties estimated between 150,000 to $750,000 \cdot{ }^{16}$ Moreover, hundreds of thousands of Cambodian fled rural areas for the cities, seeking refuge from US military action and an increasingly brutal civil war. When the Khmer Rouge captured Phnom Penh on April 17, 1975, the city's population had swelled from 1.5 million to 3 million; upwards of 80 percent of this growth is attributed by rural refugees. ${ }^{17}$

For many people in Cambodia-but especially those finding refuge in Phnom Penh-hunger was an ever-present reality. In the capital city, food was hard to come by, because of corruption, infrastructure collapse, and the destruction of farms and fields. By war's end, approximately one-third of the country's bridges were destroyed, two-fifths of the road network was unusable, and the railroad was inoperable. The extensive destruction wrought by the sustained bombing campaigns ravaged agricultural production: between 1970 and 1973, for example, the area under rice cultivation decreased by 77 percent and the total rice harvest decreased by 84 percent. $^{18}$ Upwards of half of Cambodia's livestock had been killed, either through fighting or bombing or as a food source for the starving people. And when food was available, it was often unaffordable owing to rampant inflation. ${ }^{19}$

The violence of armed conflict provides the necessary context for understanding the conditions of the evacuation of Phnom Penh and, by extension, for situating the lived experiences of evacuees. As Emma Laurie and Ian Shaw explain, from economic conditions, to ecological conditions, to psychological conditions, geography maps the inescapable situatedness of being. ${ }^{20}$ They continue: "Conditions are the very geographies of being: the existential resources that nourish and sustain, but also harm and violate." ${ }^{21}$ In effect, years of war conditioned but did not determine the geographies of evacuation.

\footnotetext{
${ }^{14}$ Curtis, et al., Spatial Video Geonarratives.

${ }^{15}$ Ben Kiernan, “The American Bombardment of Kampuchea, 1969-1973," Vietnam Generation 1, no. 1 (1989), 4-41; Ben Kiernan and Taylor Owen, "Making More Enemies than We Kill? Calculating U.S. Bomb Tonnages Dropped on Laos and Cambodia, and Weighing Their Implications," Asia-Pacific Journal 13, no. 16 (2015), 1-9; James A. Tyner and Gordon Cromley, "Camps, Cooperatives and the Psychotopologies of Democratic Kampuchea," Area (2018), accessed November 20, 2018, https://doi.org/10.1111/area.12423.

${ }^{16}$ Taylor Owen and Ben Kiernan, "Bombs over Cambodia," The Walrus October (2006), 62-69; John Tully, A Short History of Cambodia: From Empire to Survival (Crows Nest, Australia: Allen \& Unwin, 2005).

${ }^{17}$ Ben Kiernan, The Pol Pot Regime: Race, Power, and Genocide in Cambodia under the Khmer Rouge, 1975-79 (New Haven: Yale University Press, 2002).

${ }^{18}$ Henry J. Nesbitt, Rice Production in Cambodia (Los Baños, Philippines: International Rice Research Institute, 1997). See also William Shawcross, Sideshow: Kissinger, Nixon, and the Destruction of Cambodia, revised edition (New York: Cooper Square Press, 2002).

${ }^{19}$ Arnold Isaacs, Without Honor: Defeat in Cambodia (Baltimore: Johns Hopkins University Press, 1983); Noam Chomsky and Edward S. Herman, After the Cataclysm: Postwar Indochina and the Reconstruction of Imperial Ideology (Chicago: Haymarket Books, 2014).

${ }^{20}$ Emma W. Laurie and Ian G.R. Shaw, “Violent Conditions: The Injustices of Being," Political Geography 65 (2018), 8.

${ }^{21}$ Ibid.
} 
When Khmer Rouge troops entered Phnom Penh as victors on April 17, 1975 they constituted neither a centralized, efficient political party nor military force. Indeed, occupying forces in the capital city are estimated to have numbered approximately 20,000. Not surprisingly, security concerns were prominent among senior leaders of the CPK. As Lek Hor Tan writes, Khmer Rouge officials feared especially that the United States would resume its bombing campaign in an attempt to restore Lon Nol to power. In addition, hunger and disease were widespread throughout the city; and both of these conditions could spark massive protests and violence. ${ }^{22}$ However, to focus exclusively on the immediate conditions of Phnom Penh is to lose sight of the broader material objectives of the Khmer Rouge. Indeed, the decision to evacuate Phnom Penh apparently was made sometime in February 1975 and was part of Khmer Rouge standard operating procedure when territories were captured. Quite simply, the evacuation of cities, market towns, and villages was a long-standing practice of the Khmer Rouge. ${ }^{23}$ As early as $1971 \mathrm{Khmer}$ Rouge forces began to systematically burn villages and hamlets that fell under their control as they attempted to 'liberate' the country and various forms of communes and co-operatives were established as early as 1973. In 1973, for example, Khmer Rouge soldiers seized half of Kompong Cham City, forcing upwards of 15,000 people into the countryside, while in March 1974 Khmer Rouge forces emptied the former capital of Oudong, relocating more than 20,000 former residents onto agricultural communes. ${ }^{24}$ Consequently, the proximate concerns of security, famine, and health were paramount; but these conditions underscored existing Khmer Rouge practice for a post-conflict society.

To achieve industrial self-sufficiency, the CPK decreed that they would "only have to earn [foreign] capital from agriculture." ${ }^{25}$ In practice, therefore, the CPK sought to extend production through deforestation and large-scale irrigation schemes. ${ }^{26}$ The CPK subsequently coupled this objective with the "relentless enhancement and expansion of cooperatives." ${ }^{27}$ Hence, immediately preceding and following victory in 1975, the CPK intensified its effort to bring together its citizenry in the form of camps in order to achieve its economic objectives, namely the rapid increase in agricultural crops for export. Initially, however, there was scant coordination in the establishment of agricultural collectives-a problem that translated into the chaotic nature of the evacuation of Phnom Penh.

\section{Spatial Video Geonarrative as Methodology}

Personal narratives, whether in the form of oral histories or witness testimonies, provide valuable insight into the practice and experience of genocide and mass violence. As Mei-Po Kwan and Guoxiang Ding explain, as a research method, the focus of narrative analysis is not only on people's experiences as stories but also on illuminating the social, cultural, and institutional contexts within which those experiences were constituted, shaped, expressed, and enacted..$^{28}$ The use of personal narratives, however, is not without its problems. Indeed, all research-no matter how objectively pursued - is confronted with some degree of uncertainty. Here, uncertainty covers a broad range of doubts or inconsistencies and is not necessarily synonymous with 'error' ${ }^{29}$ Following Burleson and Giordana, we can identify two primary forms of uncertainty: Ambiguous uncertainty, which

\footnotetext{
${ }^{22}$ Lek Hor Tan, “Cambodia's Total Revolution," Index on Censorship 8, no. 1 (1979), 3-10.

${ }^{23}$ Tyner et al., Phnom Penh, 1876.

${ }^{24}$ Ben Kiernan, How Pol Pot Came to Power: A History of Communism in Kampuchea, 1930-1975 (London: Verso, 1985); Kenneth M. Quinn, “The Pattern and Scope of Violence," in Cambodia 1975-1978: Rendezvous with Death, ed. Karl D. Jackson (Princeton: Princeton University Press, 1989), 179-208.

${ }^{25}$ Party Center of the Communist Party of Kampuchea, Preliminary Explanation, 96.

${ }^{26}$ James A. Tyner, Mandy Munro-Stasiuk, Corrine Coakley, Sokvisal Kimsroy, and Stian Rice, “Khmer Rouge Irrigation Schemes during the Cambodian Genocide," Genocide Studies International 12, no. 1 (2018), 103-119.

${ }^{27}$ Document E3/748, “Some Important Excerpts from the First Nationwide Party Economic Congress November 1975," archived by the Extraordinary Chambers in the Courts of Cambodia (ECCC) at http://www.eccc.gov.kh/en.

${ }^{28}$ Mei-Po Kwan and Guoxiang Ding, “Geo-Narrative: Extending Geographic Information Systems for Narrative Analysis in Qualitative and Mixed-Method Research," The Professional Geographer 60, no. 4 (2008), 448.

${ }^{29}$ Alan M. MacEachren, Anthony Robinson, Susan Hopper, Steven Gardner, Robert Murray, Mark Gahegan, and Elisabeth Hetzler, "Visualizing Geospatial Information Uncertainty: What We Know and What We Need to Know," Cartography and Geographic Information Science 32, no. 3 (2005), 140.
} 
describes characteristics of the data itself, and fuzzy uncertainties, which relate to the historical event. ${ }^{30}$ With respect to the evacuation of Phnom Penh, there remains considerable fuzzy uncertainty as to the decision-making of the Khmer Rouge; as well as the micro-geographies of when different parts of the city were evacuated. The ambiguous uncertainty relates to the observation that despite myriad personal accounts of the evacuation, we actually understand little of the evacuation from a comparative standpoint. That is, scant empirical work has addressed the evacuation and, consequently, our understanding is based on the compilation of memoirs and other forms of oral histories. The ambiguous uncertainties surrounding the evacuation emanate from the paucity of systematic accounts of the event that effectively capture the spatial variability of the evacuation.

A key element of uncertainty is associated with the source of the information, especially human reporting, memoirs, and other forms of personal communication. ${ }^{31}$ It is of course disconcerting to question the reliability or accuracy of survivor accounts; and yet, the issue of uncertainty remains salient, in that "the credibility of human sources is a complex issue, combining elements of general human perception and unconscious bias, specific characteristics that affect accuracy, and deliberate decisions ranging from embellishment to outright deception." ${ }^{32}$ Difficulties increase when we add an historical component. Both perception and memory are selective and interpretive; and uncertainty deepens when individuals retell their narratives many years, if not decades, after the actual event. ${ }^{33}$ In our present study, for example, most of the participants were children during the time of the evacuation, and they readily acknowledge the difficulties of remembering. According to Participant \#3, "I cannot remember everything for sure because one I was a kid and two I had never been elsewhere before." Here, he explains the difficulties of recollection; and of the fact that he experienced the evacuation as a child of about twelve years old, and yet was providing an understanding from the vantage of being an adult. For this reason, we premise, the use of SVG provides a more robust methodology to offset partially the problems inherent to long-term remembrance.

The benefit of SVG is that the physical environment, interviewee, and interviewer interact in a way that provides a necessary geographic context to personal narratives. Locational cues, for example, may trigger specific recollections and thereby contribute to a deeper, more nuanced understanding of previous experiences. Moreover, through the overlay, or compilation of several individual narratives, we achieve the triangulation necessary to gain previously unrecorded insight about places and their interactions at the finest scale, something that is not possible through individual memoirs or testimonies in isolation. ${ }^{34}$ Indeed, the use of SVG permits researchers the opportunity to link video to places and experiences and thereby enrich our spatial understanding.

During two separate field stints in 2017, our team collected six SVGs of individuals who participated in the evacuation of Phnom Penh. Participants were identified using snow-ball procedures. Most of the participants were young boys during the time of the evacuation; were longtime residents of Phnom Penh; and each had evacuated with their families. Data collection consisted of GPS enabled contour +2 cameras mounted on the inside window of the left and right side of a vehicle; two audio recorders were placed on or around the subject, who was sitting in the front seat. Prior to the geospatial interview, we provided participants a brief description of the project rationale and asked for verbal consent for their participation in keeping with protocol established by the Institutional Review Board of Kent State University. Each interview lasted between 60 and 90 minutes; the subject dictated the route to the driver-a native Khmer speaker and research colleague - to conform as closely as possible to his/her evacuation path. We specifically asked each participant to retrace the route they undertook during the evacuation; and to describe what they saw, felt, experienced. After data collection, our team transcribed all narratives and subsequently translated these into English. Time stamps were inserted proceeding each comment, for example:

\footnotetext{
${ }^{30}$ Burleson and Giordana, Extending Metadata Standards, 93.

${ }^{31}$ Judi Thomson, Elizabeth Hetzler, Alan MacEachren, Mark Gahegan, and Misha Pavel, “A Typology for Visualizing Uncertainty," Proceedings of SPIE 5669 (2005), 147. 
[00:23:54] Along the road, patients were abandoned in the fields. I saw them being left alone on the bed. They were in the fields. I guess the medical staff members were ordered to move those patients out of the hospitals, and when they got out of the city and did not see or know any relatives of those patients ... then they just abandoned those patients. Here, in this narrative extract, the participant recalls information triggered by the participant driving past what was then a vacant field; his physically being at the location sparked particular memories about what happened at that place.

Following transcription, project members read and coded each narrative for themes to guide subsequent analyses. The analysis of geospatial narratives is an iterative process; and while project members may approach the study with general categories known beforehand (e.g., concerns of direct violence, hardship, exhaustion during the evacuation), the robustness of the geonarrative, both contextually and spatially, expands the list of categories for further investigation. More precisely, participants' georeferenced cues about key events and places surface inductively as primary avenues of research. Crucially, genarratives provide insight into the physical conditions of Phnom Penh during the evacuation, conditions that are far removed from the city experienced today. In 1975 Phnom Penh was a smaller, more compact city; indeed, the distance from the 'downtown' hub of the city and the rural hinterlands was not so great as it is now. Moreover, the city was less dense; there were many more vacant fields, rice paddies, and fish ponds - a landscape vastly different from the congested megacity of Phnom Penh today.

Computationally, we extracted also a global positioning system (GPS) path from the audiovideo recordings using Contour Storyteller software; this permits us to layer participants' geonarratives onto a composite image. In this paper we provide one component of our analysis, this being the micro-geographies of evacuation routes out of Phnom Penh. As a preliminary investigation, we suggest that this aspect of the evacuation has received insufficient empirical focus and, in turn, may provide a necessary spatial context for understanding post-evacuation practices undertaken by officials of the CPK.

\section{Retracing the Evacuation}

A composite image of participants' SVG illustrates vividly the circuitous routes of the evacuation (Figure 1). Indeed, preliminary evidence suggests that evacuees did not, and equally important, were not necessarily forced to take the most direct (hence, efficient) path out of the city. This observation provides insight into both the confusion and deliberate decisions undertaken by evacuees under the threat of violence. To begin: Documentary evidence, combined with testimony provided by both survivors and former Khmer Rouge soldiers suggests that little planning went into the specific procedures. ${ }^{35}$ Regardless of the degree of forethought into the evacuation, the actual displacement involved considerable uncertainty-some of which was deliberate, while other aspects were the result of the 'fog of war.' For example, Khmer Rouge soldiers deceptively told evacuees that they could return in three days. However, senior commanders apparently provided Khmer Rouge soldiers with contradictory orders and incomplete information. To this end, it remains uncertain if some of the rank-and-file Khmer Rouge soldiers did not actually believe the rouse perpetrated by their superiors.

The chaos and confusion of the evacuation process provides a necessary condition in understanding individual pathways away from the city. Informed that the evacuation would last only two or three days, many families only took sufficient supplies, such as food and water, to last a short duration. Participant \#5 explains: "We were worried. We were not certain whether the Khmer Rouge were lying to us or telling us the truth. They said we would leave for only three days, so we did not pack enough food to eat."

Still other families disbelieved the evacuation orders and, for one or two days, attempted to carry on with their lives. Participant \#3 remembers, "We did not want to leave. We delayed our journey until late afternoon. We did not trust them." Participant \#2 explains that the "Khmer Rouge said they had to evacuate people out for three days" but "my two siblings continued to sell fish. On the evacuation day, my two sisters were separated from our family. They continued to sell fish.

\footnotetext{
${ }^{35}$ Boraden Nhem, The Khmer Rouge: Ideology, Militarism, and the Revolution that Consumed a Generation (Santa Barbara: Praeger, 2013).
} 


\section{Evacuation of Phnom Penh}

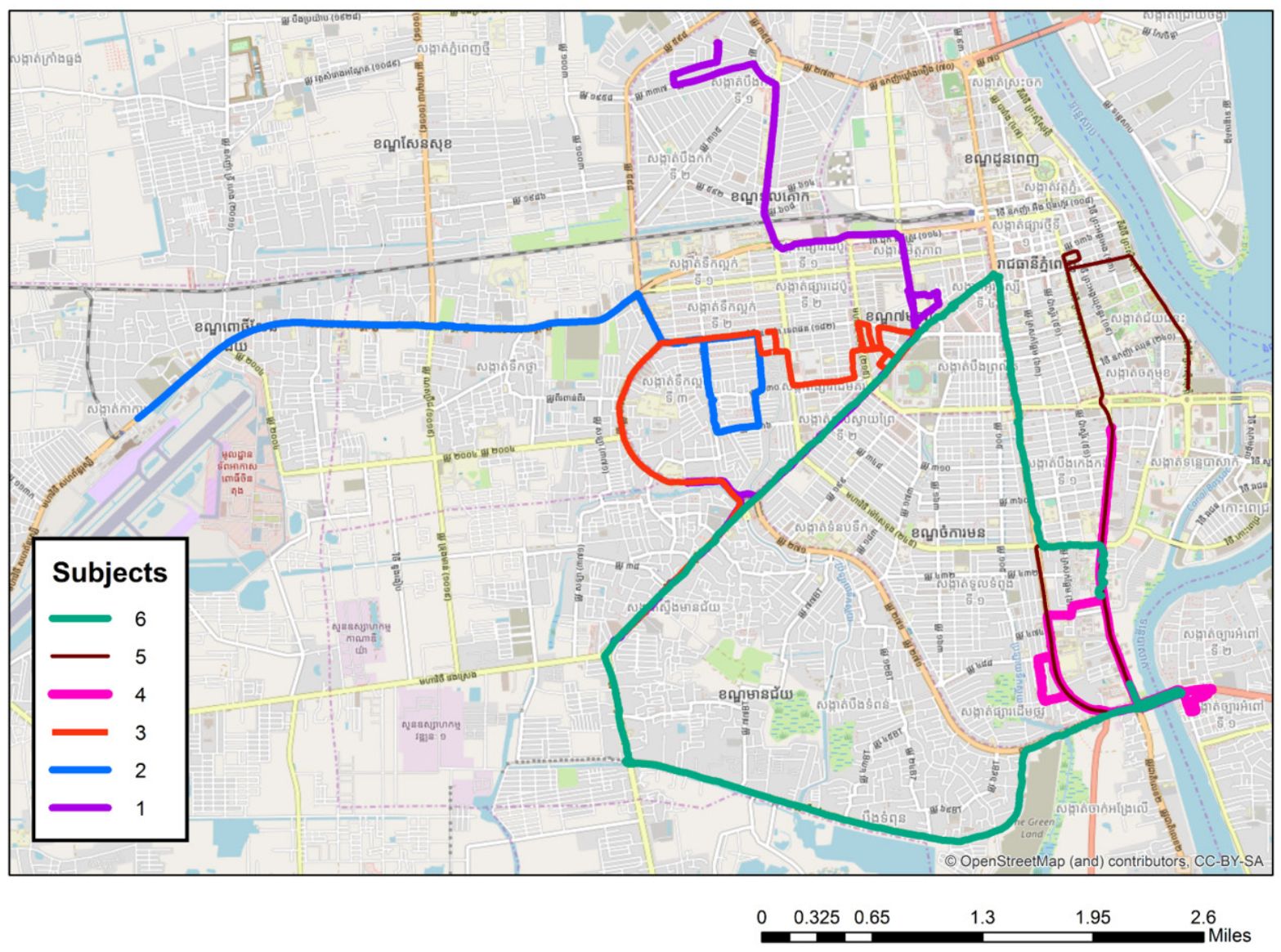

Figure 1. Composite image of evacuation routes of six participants.

They went to do business on April 17." When Participant \#2's family was forced to leave, they were unable to reconnect with the two sisters.

For those families that did not carry sufficient food and water, it became a challenge to obtain the necessary items during the evacuation. Participant \#5 explains, "We searched and went to empty houses or asked the owners to cook rice and food to eat.... [We] used well or pond water. Sometimes, we drank water without cooking or boiling it." Other families were able to purchase or trade for food, often from other households that had not yet evacuated. "At that time," Participant \#2 explains, "people were selling [rice and pork] at low prices along the roads. At that time, people continued to trade. We bought those things along the roads." For Participant \#4, however, conditions were different: "We bought some items along the roads, but everything was so expensive."

Several factors operating in combination influenced the path of evacuation out of the city, including one's location at the time of evacuation (e.g., the location of their residence), the intended destination, the mass of other evacuees, and the presence of Khmer Rouge troops. All six of the participants in this study hailed from families that were residents of Phnom Penh; consequently, all began the journey from their homes.

Having captured Phnom Penh, the Khmer Rouge divided the city into zones; in principle, residents in each zone were to be directed toward a particular path out of the city. During the evacuation, families were simply ordered to leave the city; they were not, at this point, necessarily 
directed where to go. Participant \#2 explains: "I do not think that we could freely go to our homeland. Certain people in each divided zone were supposed to go and leave the city based on their direction." In practice, many evacuees altered their routes in anticipation of joining friends or family members outside of the city. Participant \#4 describes the difficult decisions confronting his parents: "My father was from Chy Kraeng, Siem Reap. He said he wanted to go there, and my father often went to visit my mother's homeland in Prey Veng.... At that time, my mother insisted of going to her place because she had relatives there.... We could ask them for help because they had come and asked for our help in Phnom Penh. They came and visited, and we took them to the hospital for medical checkup." Here, the difficulty was compounded because Siem Reap is to the northwest of the city and Prey Veng is in the opposite direction, to the southeast. Consequently, the initial decision was often of primary importance, in that Khmer Rouge soldiers would prevent evacuees from reversing course. Participant \#4 expands that people "could not return freely... [The Khmer Rouge soldiers] blocked the roads and only let people move out." He concludes, "No one could come from our different direction. When the Khmer Rouge came, they fired into the air ... because it was too crowded. They fired into the air so that people could make way for them."

During the course of the evacuation, families often decided to alter their course. For example, from their initial location, Khmer Rouge soldiers might direct families to leave toward the northwest. However, as illustrated by Participant \#4, the family may decide that their best course of action is to rejoin family members to the southwest. This decision would force evacuees, if possible, to circle back toward their preferred route. According to Participant \#1, "After crossing Sla Kou Bridge, we decided that we would return to our [father's] homeland.... We wanted to go to my father's homeland, because it would be hard and a long distance to go to my mother's homeland. Therefore, we had to go to my father's place. We turned our direction...." Participant \#1 describes a similar experience: "We went straight and then turned. We went through such direction because we wanted to visit our rented house. We went there and were supposed to turn, but the Khmer Rouge did not allow us. They forced us to go through here."

Other families, also hoping to avoid leaving the city, attempted to hide. Participant \#5 explains that his family sought to hide in his uncle's house. However, the Khmer Rouge soldiers were everpresent and his family was caught. "They said that if they say us hiding next time," Participant \#5 recalls, "they would shoot us dead." The family of Participant \#4 likewise held out for two or three days before eventually leaving the city: "We did not leave on April 17, but many people left. I think we left our home on April 19 or April 20." For this family, the added days were spend in preparation of the likelihood of evacuation. "My father prepared some stuff," Participant \#4 remembers. "My father was secretly making a cart. He thought of bringing some items [to] exchange them along the way." Moreover, he continues, "before leaving our home, I went to one place with other people, and there were lots of packed noodles there."

As indicated earlier, the Phnom Penh of 1975 was considerably smaller and less dense than it is today; there were numerous vacant fields, rice paddies, and fish ponds. All these sites became places of temporary refuge, as evacuees sought respite from the heat or to rest. Participant \#2 recalls, "During mealtime, we tried to find a place or shade where we could stop and cook rice." Participant \#1 also remembers: "We tried to find houses where we could seek shelter. There were wooden houses near the drainage system or canal." Seeking shelter, however, often held traumatic consequences. For the first night, Participant \#1 explains, "we went in [one house] and checked whether we could stay and cook there. However, we could not find one, because of the smell. There were dead and swollen bodies inside those houses... We went in and checked many houses, and they smelled [because of decomposing bodies]."

Sanitary facilities, and the ability to urinate or defecate, were ever-present problems for the evacuees. "There were no toilets, and there were thousands of people," Participant \#2 remembers. He continues: "There were too many people, and there were feces everywhere, and it smelled bad. People did not go and defecate further from the road." When combined with the necessity of drinking water from polluted ponds or canals, health problems were recurrent. During the interview, Participant \#4 points to a location, now a densely crowded neighborhood but then, a small lake. "We had stomach-aches and diarrhea there," he explains. 
During the evacuation, bridges assumed tremendous importance, as these became choke points for the masses of men, women, and children. Figures 2 and 3 illustrate the convergence of multiple evacuation routes across Monivong Bridge and the bridge at Veng Sreng Boulevard, respectively. At both locations, participants converged at these bridges, despite having traveled different paths. Indeed, Monivong Bridge assumes importance as it was one of the few bridges in existence to cross the Bassac River and, consequently, myriad columns of people converged on the site. Importantly, the convergence of paths added to the congestion and confusion. "People were pushing each to move forward," Participant \#5 remembers. He adds: "It was very crowded." Participant \#4 also remembers that at the bridge, "We could move very slowly. We got stuck on the bridge until $4 \mathrm{pm}$ or $5 \mathrm{pm}$... It was very difficult traveling on the bridge. It was hot, and we were thirsty."

\section{Bridge at Veng Sreng Boulevard}

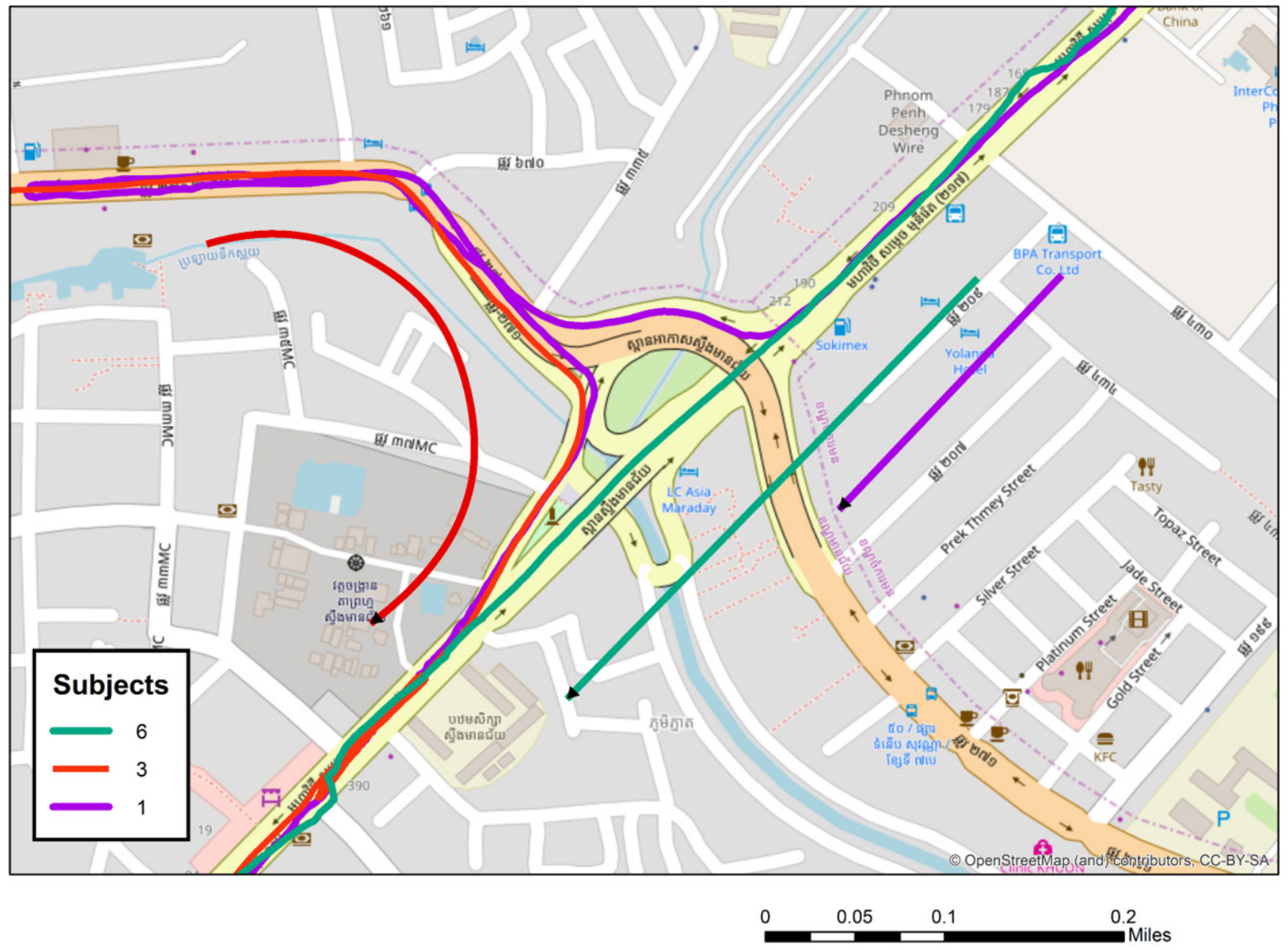

Figure 2. Convergence of routes at bridge along Veng Sreng Boulevard.

During the war, many bridges were destroyed and this contributed to the difficulties of evacuation. Participant \#1 explains, "We left this area ... through the National Road 3. I know this because I remember too well that we went through Sla Kou Bridge. I remember because they bridge was broken at that time. People had to cross the water, which was flowing fast. People had to find a way to cross it."

Bridges also became symbolic focal points. During the time of the evacuation, Phnom Penh, as indicated, was considerably smaller and less dense. Bridges, such as the Monivong Bridge or 
the bridge at Veng Sreng Boulevard (Figure 3) were located at the outskirts of the city. Participant \#1 explains: "When we reached the outskirt, we waited near Stung Maenchey Bridge. We thought that they would let us go back, because they said that they let us get out for only three days." Not wanting to leave their homes, many families congregated at these locations, hoping to 'wait out' the three days before they would be able to return. Participant \#1 continues: "Those people did not want to walk fast. They wandered around this area, hoping that after three days, they would be able to return."

The emotional trauma and physical hardships of the evacuation intensified at these geographic points of convergence. It is not surprising that participants recall scenes of violence, including the sight of dead bodies, at these locations. Participant \#1 remembers, "After crossing the bridge, I began to see dead bodies along the road. We saw the bodies, but what the elderly people tried to do was to make us walk further and avoid seeing those bodies."

\section{Converging at Monivong Bridge}

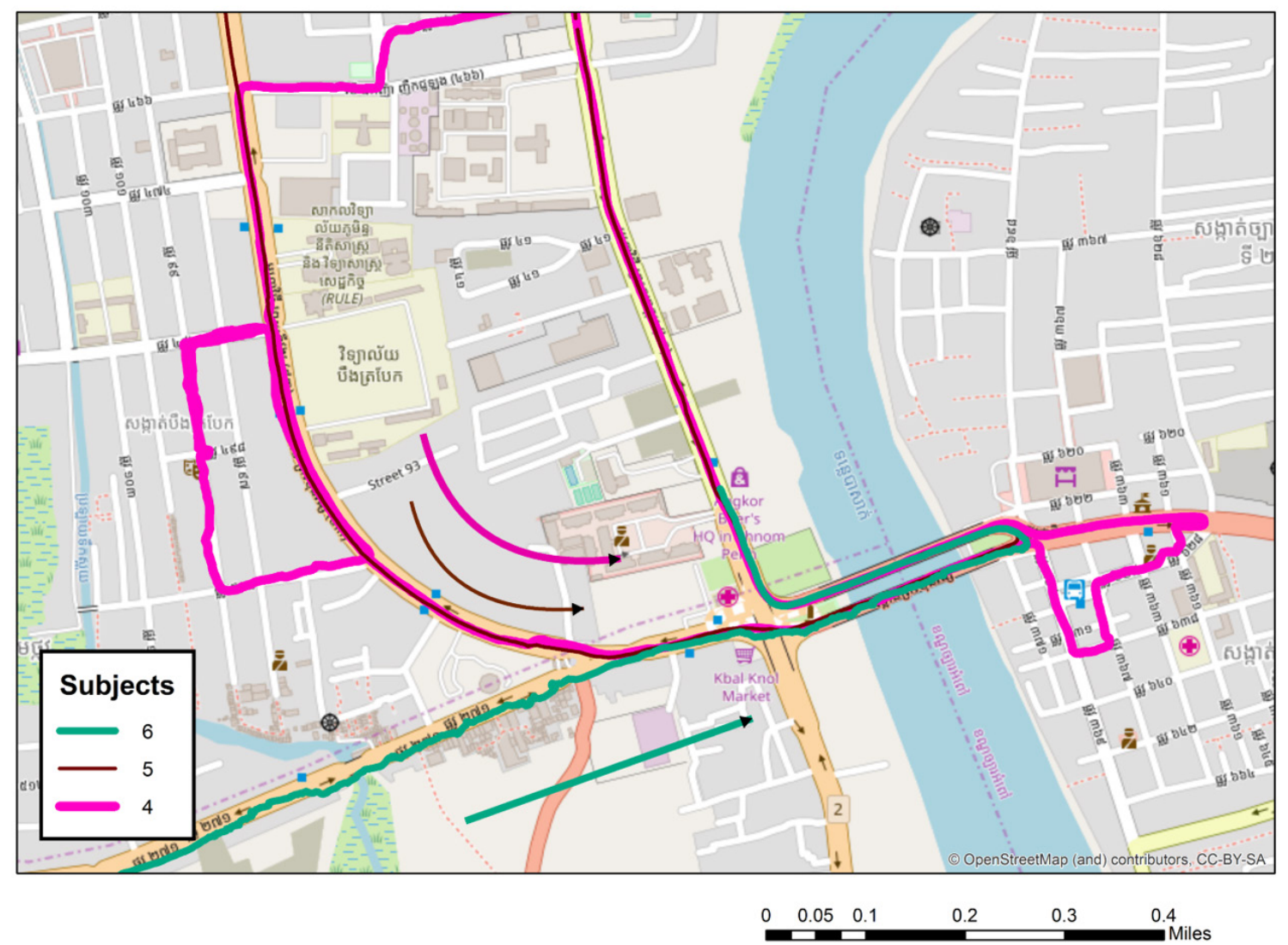

Figure 3. Convergence of routes at Monivong Bridge.

In none of the narratives was there a consistent Khmer Rouge presence; families may walk for long stretches where there were no soldiers. Likewise, Khmer Rouge soldiers were not always present when families sought shelter at night. According to Participant \#1, at night, "there were no Khmer Rouge guarding us." Indeed, it was more likely that evacuees encountered soldiers only at key locations, such as major intersections or bridges (Figure 4). [According to Participant \#4, "The main road was very crowded, so people walked along the small roads. The Khmer Rouge pushed them to move forward... And we heard gunshots." 


\section{SVG "Soldier" Mentions}

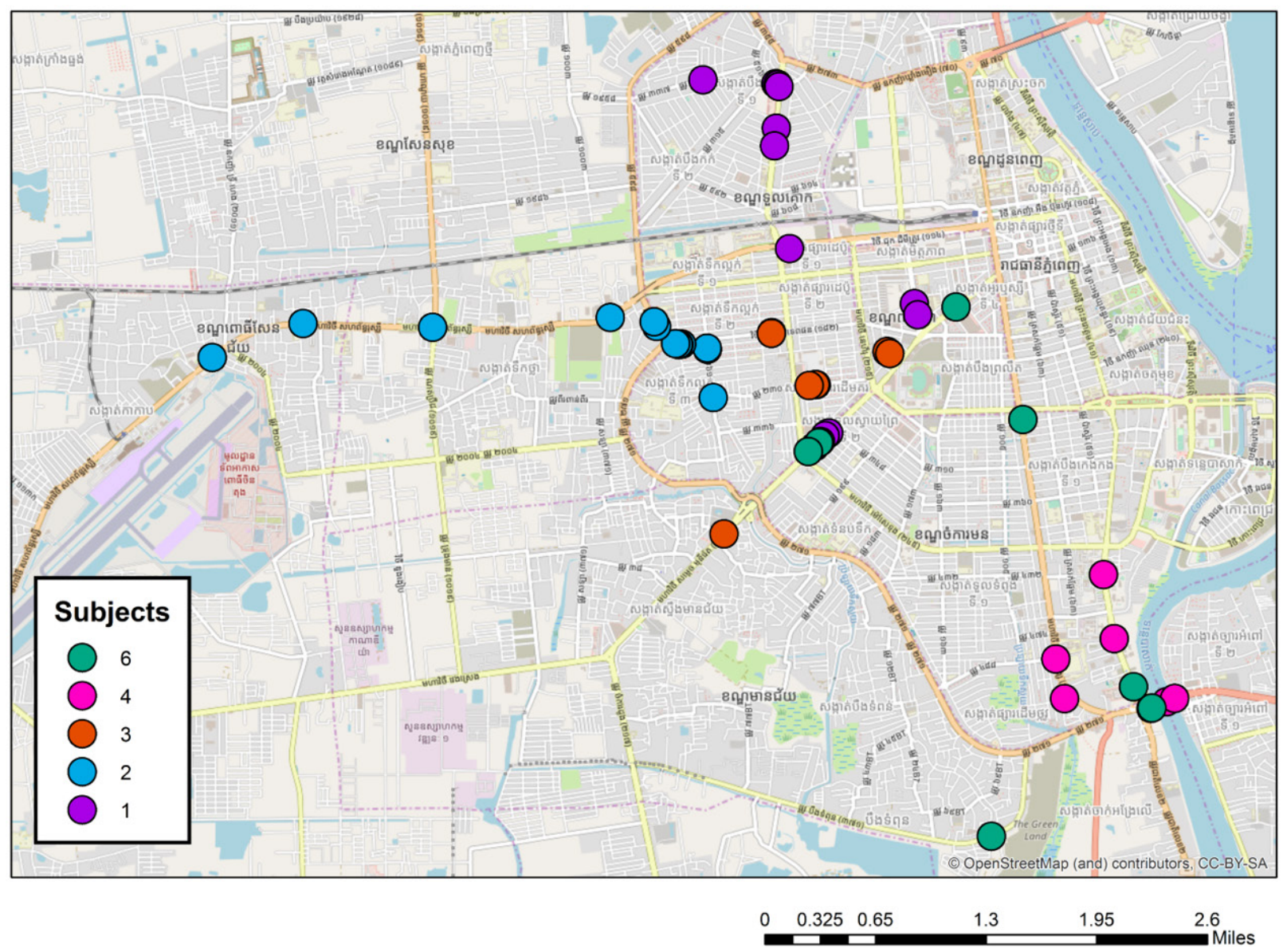

Figure 4. Location of Khmer Rouge Soldiers based on Evacuee Interviews.

\section{Conclusions}

The evacuation of Phnom Penh beginning on April 17, 1975 is a key moment in the unfolding genocide that gripped Cambodia between 1975 and 1979. However, despite myriad references to this event, both in scholarly and popular accounts, there exists scant empirical analysis of the lived experiences of the evacuation. This lacuna translates into a myopic understanding of the evacuation and thus calls to question interpretations of post-evacuation Khmer Rouge policy and practice.

In this article, we provide a systematic examination of the evacuation, as retraced by individuals who lived through the event. With a novel geospatial technology, that is, spatial video geonarratives (SVG), we provide insight into the experiences of survivors as they make sense, retroactively, of the micro-geographies of evacuation. In so doing, our analytic procedures provide a multimedia environment for the compilation, interpretation, and analysis of participants' oral histories. Key findings include the identification of circuitous routes of evacuation, the manifestation of choke points as sites of violence, and the haphazard presence of Khmer Rouge soldiers. Crucially, while narratives and memoirs describe in general the physical and emotional toll of the evacuation, our analysis provides insight into the specific routes taken; where conditions worsened; and where soldiers were stationed.

As a part of an on-going project that uses geospatial technologies to better understand the Cambodian genocide, this paper is not without its limitations. A key shortcoming of this paper- 
and the basis of our future work - is that of a diversity of social conditions. More precisely, it is necessary to capture more effectively the diversity of experiences of the evacuation. In this preliminary investigation, all participants were at the time young boys; and all were of families of long-term residency in Phnom Penh. Missing from our account are the experiences of women and of peasants who had recently arrived in Phnom Penh. Also required are interviews of former Khmer Rouge soldiers, for their experiences will provide insight into the micro-geographies of enforcement during the evacuation. Despite these exclusions, we conclude that this empirical investigation of the evacuation of Phnom Penh reveals, first, several insights heretofore neglected in previous studies and, second, the feasibility of spatial video geonarratives as a robust methodology for the study of genocide and mass violence.

\section{Acknowledgements}

This research was funded in part by the College of Arts \& Sciences at Kent State University. We are grateful for the support of Dean Jim Blank.

\section{Bibliography}

Beorn, Waitman, Tim Cole, Simone Gigliotti, Alberto Giordano, Anna Holian, Paul B. Jaskot, Anne Kelly Knowles, Marc Masurovsky, and Erik B. Steiner. "Geographies of the Holocaust." Geographical Review 99, no. 4 (2009), 563-574. https://doi.org/10.1111/j.1931-0846.2009. $\underline{\mathrm{tb} 00447 . \mathrm{x}}$

Bishop, Ryan and Gregory Clancey. "The City-As-Target, or Perpetuation and Death." In Cities, War, and Terrorism: Towards an Urban Geopolitics, edited by Stephen Graham, 54-74. Malden: Blackwell, 2004. https://doi.org/10.1002/9780470753033.ch3

Burleson, Shelley J. and Alberto Giordana. "Extending Metadata Standards for Historical GIS Research: A Case Study of the Holocaust in Budapest and the Armenian Genocide in Turkey." International Journal of Applied Geospatial Research 6, no. 4 (2015), 88-109. https:// doi.org/10.4018/ijagr.2015100105

--------. "Spatiality of the Stages of Genocide: The Armenian Case." Genocide Studies and Prevention 10, no. 3 (2016), 39-58. https://doi.org/10.5038/1911-9933.10.3.1410

Card, Brittany L. and Isaac L. Baker. "GRID: A Methodology Integrating Witness Testimony and Satellite Imagery Analysis for Documenting Alleged Mass Atrocities." Genocide Studies and Prevention 8, no. 3 (2014), 49-61. https://doi.org/10.5038/1911-9933.8.3.5

Chandler, David. The Tragedy of Cambodian History: Politics, War, and Revolution since 1945. New Haven: Yale University Press, 1999.

Chomsky, Noam and Edward S. Herman. After the Cataclysm: Postwar Indochina and the Reconstruction of Imperial Ideology. Chicago: Haymarket Books, 2014.

Clark, Mary M. "Holocaust Video Testimony, Oral History, and Narrative Medicine: The Struggle Against Indifference." Literature and Medicine 24, no. 2 (2005), 266-282. https://doi. org/10.1353/lm.2006.0002

Curtis, Andrew, Jacqueline W. Curtis, Lauren C. Porter, Eric Jefferis, and Eric Shook. "Context and Spatial Nuance Inside a Neighborhood's Drug Hotspot: Implications for the Crime-Health Nexus." Annals of the American Association of Geographers 106, no. 4 (2016), 819-836.

Curtis, Andrew, Jacqueline W. Curtis, Eric Shook, Steve Smith, Eric Jefferis, Lauren Porter, Laura Schuch, Chaz Felix, and Peter R. Kerndt. "Spatial Video Geonarratives and Health: Case Studies in Post-Disaster Recovery, Crime, Mosquito Control and Tuberculosis in the Homeless." International Journal of Health Geographics 14, no. 1 (2015), 22. https://doi. org/10.1186/s12942-015-0014-8

Curtis, Andrew and Jacqueline W. Mills. "Spatial Video Data Collection in a Post-Disaster Landscape: The Tuscaloosa Tornado of April 27, 2011." Applied Geography 32 (2012), 393400. https://doi.org/10.1016/j.apgeog.2011.06.002

Isaacs, Arnold, Without Honor: Defeat in Cambodia. Baltimore: Johns Hopkins University Press, 1983.

Kiernan, Ben. How Pol Pot Came to Power: A History of Communism in Kampuchea, 1930-1975. London: Verso, 1985. 
------. “The American Bombardment of Kampuchea, 1969-1973.” Vietnam Generation 1, no. 1 (1989), 4-41.

-------. The Pol Pot Regime: Race, Power, and Genocide in Cambodia under the Khmer Rouge, 1975-79. New Haven: Yale University Press, 2002.

Kiernan, Ben and Taylor Owen. "Making More Enemies than We Kill? Calculating U.S. Bomb Tonnages Dropped on Laos and Cambodia, and Weighing Their Implications." Asia-Pacific Journal 13, no. 16 (2015), 1-9.

Knowles, Anne K., Tim Cole, and Alberto Giordano, eds, Geographies of the Holocaust. Indianapolis: Indiana University Press, 2014.

Kwan, Mei-Po and Guoxiang Ding. "Geo-Narrative: Extending Geographic Information Systems for Narrative Analysis in Qualitative and Mixed-Method Research." The Professional Geographer 60, no. 4 (2008) 443-465. https://doi.org/10.1080/00330120802211752

Laurie, Emma W. and Ian G.R. Shaw. "Violent Conditions: The Injustices of Being." Political Geography 65 (2018), 8-16. https://doi.org/10.1016/j.polgeo.2018.03.005

MacEachren, Alan M., Anthony Robinson, Susan Hopper, Steven Gardner, Robert Murray, Mark Gahegan, and Elisabeth Hetzler. "Visualizing Geospatial Information Uncertainty: What We Know and What We Need to Know." Cartography and Geographic Information Science 32, no. 3 (2005), 139-160. https://doi.org/10.1559/1523040054738936

Madden, Marguerite and Amy Ross. "Genocide and GIScience: Integrating personal Narratives and Geographic Information Science to Study Human Rights." The Professional Geographer 61, no. 4 (2009), 508-526. https://doi.org/10.1080/00330120903163480

McIntyre, Kevin. "Geography as Destiny: Cities, Villages and Khmer Rouge Orientalism." Comparative Studies in Society and History 38 (1996), 730-758. https://doi.org/10.1017/ S001041750002051X

Mertha, Andrew. Brothers in Arms: Chinese Aid to the Khmer Rouge, 1975-1979. Ithaca: Cornell University Press, 2014. https://doi.org/10.7591/cornell/9780801452659.001.0001

Mills, Jacqueline W., Andrew Curtis, Barrett Kennedy, S. Wright Kennedy, and Jay D. Edwards. “Geospatial Video for Field Data Collection." Applied Geography 30 (2010), 533-547. https:// doi.org/10.1016/j.apgeog.2010.03.008

Nesbitt, Henry J.. Rice Production in Cambodia. Los Baños, Philippines: International Rice Research Institute, 1997.

Nhem, Boraden. The Khmer Rouge: Ideology, Militarism, and the Revolution that Consumed a Generation. Santa Barbara: Praeger, 2013.

Owen, Taylor and Ben Kiernan. "Bombs over Cambodia." The Walrus October (2006), 62-69.

Party Center of the Communist Party of Kampuchea. "Preliminary Explanation Before Reading the Plan, by the Party Secretary." In Pol Pot Plans the Future: Confidential Leadership Documents from Democratic Kampuchea, 1976-1977, edited by David Chandler, Ben Kiernan, and Chanta Boua, 119-163. New Haven: Yale University Press, 1988.

Ponchaud, François. Cambodia Year Zero, translated by Nancy Amphoux. New York: Holt, Rinehart, and Winston, 1978.

Quinn, Kenneth M. "The Pattern and Scope of Violence." In Cambodia 1975-1978: Rendezvous with Death, edited by Karl D. Jackson, 179-208. Princeton: Princeton University Press, 1989.

Rice, Stian and James A. Tyner. "The Rice Cities of the Khmer Rouge: An Urban Political Ecology of Rural Mass Violence." Transactions of the Institute of British Geographers 42 (2017), 559-571. https://doi.org/10.1111/tran.12187

Seng, Vatey. The Price We Paid: A Life Experience in the Khmer Rouge Regime, Cambodia. Lincoln: iUniverse, 2005.

Shaw, Martin. What is Genocide? Malden: Polity Press, 2007.

Shawcross, William Sideshow: Kissinger, Nixon, and the Destruction of Cambodia, revised edition. New York: Cooper Square Press, 2002.

Thomson, Judi, Elizabeth Hetzler, Alan MacEachren, Mark Gahegan, and Misha Pavel "A Typology for Visualizing Uncertainty." Proceedings of SPIE 5669 (2005), 146-158. https:// doi.org/10.1117/12.587254 
Tully, John. A Short History of Cambodia: From Empire to Survival. Crows Nest, Australia: Allen \& Unwin, 2005.

Tyner, James A. "Violence, Surplus Production, and the Transformation of Nature during the Cambodian Genocide." Rethinking Marxism 26 (2014), 490-506. https://doi.org/10.1080/08 935696.2014.947756

-------. From Rice Fields to Killing Fields: Nature, Life, and Labor under the Khmer Rouge. Syracuse: Syracuse University Press, 2017.

Tyner, James A. and Gordon Cromley. "Camps, Cooperatives and the Psychotopologies of Democratic Kampuchea." Area (2018). Accessed November 20, 2018. https://doi.org/10.1111/ area.12423

Tyner, James A., Samuel Henkin, Savina Sirik, and Sokvisal Kimsroy. "Phnom Penh during the Cambodian Genocide." Environment and Planning A: Economy and Space 46 (2014), 18731891. https://doi.org/10.1068/a130278p

Tyner, James A., Mandy Munro-Stasiuk, Corrine Coakley, Sokvisal Kimsroy, and Stian Rice "Khmer Rouge Irrigation Schemes during the Cambodian Genocide." Genocide Studies International 12, no. 1 (2018), 103-119. https://doi.org/10.3138/gsi.12.1.07

Tyner, James A. and Stian Rice. "Cambodia's Political Economy of Violence: Space, Time, and Genocide under the Khmer Rouge, 1975-79." Genocide Studies International 10, no. 1 (2016), 84-94. https://doi.org/10.3138/gsi.10.1.07

Ung, Loung. First They Killed My Father: A Daughter of Cambodia Remembers. New York: Harper Collins, 2000. 